\title{
Hubungan Lama Pemakaian Kb Suntik Dengan Gangguan Menstruasi Pada Akseptor KB Baru
}

\author{
Omiati Natalia \\ Email: omynatalia27@gmail.com \\ Program Studi Kebidanan/ Universitas Qamarul Huda Badaruddin Bagu
}

\begin{abstract}
ABSTRAK
Penggunaan kontrasepsi merupakan salah satu variabel yang mempengaruhi fertilitas. Salah satu kontrasepsi yang sering digunakan adalah kontrasepsi suntikan. Cara kerja KB suntik adalah menghalangi ovulasi (masa subur), mengubah lendir serviks (vagina) menjadi kental, menghambat sperma dan menimbulkan perubahan pada rahim, mencegah terjadinya pertemuan sel telur dan sel sperma, mengubah kecepatan transportasi sel telur. Tujuan dari penelitian ini adalah untuk mengetahui hubungan lama pemakaian kontrasepsi KB suntik dengan gangguan menstruasi pada akseptor KB baru. Jenis penilitian ini adalah observasional analitik dengan rancangan studi potong lintang dengan jumlah sampel 68. Metode pengambilan sampel adalah total sampling. Pengumpulan data melalui wawancara terpimpin dengan kuesioner .Hasil penelitian ini menunjukkan ada hubungan antara lama pemakaian kontrasepsi KB suntik DMPA dengan gangguan menstruasi karena $\mathrm{p}$-value $=0,007<\alpha(0,05)$, dan tidak ada hubungan antara lama pemakaian kontrasepsi $\mathrm{KB}$ suntik Cyclofem dengan gangguan menstruasi karena p-value $=0,170$. Disimpulkan bahwa KB suntik DMPA berhubungan dengan gangguan menstruasi pada akseptor KB suntik baru.
\end{abstract}

Kata kunci: KB suntik, Gangguan Menstruasi, Akseptor KB

\begin{abstract}
Use of contraception is one of the variables that affect fertility. One contraceptive that is often used is injection contraception. The way the injection works is to prevent ovulation (fertile period), change cervical mucus (vaginal) into thick, inhibit sperm and cause changes in the uterus, prevent the occurrence of egg and sperm cells, change the speed of egg transport. The purpose of this study was to determine the relationship between the long-term use of injection contraception with menstrual disorders in new family planning acceptors. This type of research is an analytic observational study with a cross-sectional study design with a sample size of 68 responens. The sampling method is total sampling. Data collection through guided interviews with questionnaires. The results of this study showed that there was a relationship between the duration of use of DMPA injection contraception with menstrual disorders because of $\mathrm{p}$-value $=0.007<\alpha(0.05)$, and there was no relationship between the length of use of Cyclofem injection contraception contraception with menstrual disorders due to $\mathrm{p}$-value $=0.170$. It was concluded that DMPA injection family planning was associated with menstrual disorders in new injecting family planning acceptors.
\end{abstract}

Keywords: contraceptive injection, menstrual disorders, family planning acceptors

\section{A. LATAR BELAKANG}

International Conference on Population and Development (ICPD) pada tahun 1994 di Kairo telah merubah paradigma dalam pengelolaan masalah kependudukan, yang semula berorientasi kepada penurunan fertilitas (manusia sebagai obyek) menjadi pengutamaan kesehatan reproduksi perorangan dengan menghormati hak reproduksi setiap individu (manusia sebagai subyek). Upaya yang dilakukan dalam program KB diantaranya adalah melalui penggunaan alat kontrasepsi.

Berdasarkan data World Health Organization (WHO) jika dibandingkan dengan 
negara ASEAN lainnya, penggunaan alat kontrasepsi di indonesia cukup tinggi sebesar $61 \%$ dan melebihi rata-rata ASEAN sebesar $58,1 \%$. Akan tetapi angka tersebut lebih rendah dibandingkan dengan Vietnam (78\%), Kamboja (79\%) dan Thailand (80\%). Padahal jumlah Wanita Usia Subur (WUS) tertinggi di ASEAN adalah di indonesia yaitu 65 juta orang [1].

Perubahan paradigma dalam pengelolaan masalah kependudukan dan pembangunan dari pendektan dari pendekatan populasi dan penurunan fertilitas menjadi pendekatan yang berfokus pada kesehatan reproduksi serta hak reproduksi serta hak reproduksi maka pelayanan keluarga berencana harus menjadi lebih berkualitas serta memperhatikan hak-hak klien atau masyarakat dalam memilih metode kontrasepsi yang dipilih. Adapun macammacam metode kontrasepsi yaitu metode kontrasepsi alamiah, metode barier pria, kontrasepsi barier pada wanita, kontrasepsi hormon, Metode Amenorea Laktasi (MAL), IUD, Implan, Vasektomi, Tubektomi [2].

Salah satu kontrasepsi yang sering digunakan adalah kontrasepsi suntikan, kontasepsi suntikan di Indonesia merupakan salah satu kotrasepsi yang populer. Cara kerja $\mathrm{KB}$ suntik adalah menghalangi ovulasi (masa subur), mengubah lendir serviks (vagina) menjadi kental, menghambat sperma dan menimbulkan perubahan pada rahim, mencegah terjadinya pertemuan sel telur dan sel sperma, mengubah kecepatan transportasi sel telur [2].

Dari hasil wawancara Bidan Polindes Desa Jelantik menyatakan bahwa rata-rata keluhan akseptor KB suntik pada awal pemakaian (1-3x suntikan) yaitu sering mengeluh pola haid tidak teratur seperti perdarahan banyak, spotting (bercak), siklus haid lebih pendek dan lebih panjang. Berdasarkan informasi diatas maka peneliti tertarik untuk mengetahui Hubungan lama pemakaian kontrasepsi KB suntik dengan gangguan menstruasi pada akseptor KB baru.

\section{B. METODE PENELITIAN}

1. Lokasi Dan Rancangan Penelitian

Penelitian ini dilakukan di Desa Jelantik, Kecamatan Jonggat. Jenis penilitian ini adalah observasional analitik dengan rancangan studi potong lintang.

\section{Populasi dan Sampel}

Populasi adalah seluruh akseptor KB suntik di Desa Jelantik, Kecamatan Jonggat. Jumlah sampel pada penelitian ini adalah akseptor KB baru (4x pemakaian) sampel 68 (49 DMPA, 19 Cyclofem). Teknik sampling dengan teknik total Sampling. Total sampel sebanyak 68 responden.

\section{Metode Pengumpulan Data}

Pengumpulan data dilakukan oleh peneliti sendiri menggunakan kuesioner. Data umum yang dikumpulkan (usia, pendidikan), sosial dan ekonomi (dukungan keluarga, pekerjaan), budaya (kepercayaan tentang KB), diukur dengan wawancara menggunakan daftar pertanyaan (kuesioner). Data gangguan mentruasi seperti perdarahan banyak, spotting (bercak), siklus haid lebih pendek dan lebih panjang.

\section{Analisis Data}

Pengolahan data menggunakan bantuan SPSS. Mengetahui hubungan lama pemakaian kontrasepsi suntik dengan gangguan menstruasi pada akseptor KB baru.

\section{HASIL DAN PEMBAHASAN}

\section{Analisis Univariat}

Tabel 1 Distribusi Frekuensi Berdasarkan Lama Pemakaian KB Suntik pada Akseptor KB di Desa Jelantik, Kecamatan Jonggat

\begin{tabular}{lll}
\hline Lama Pemakaian & Frekuensi & $\begin{array}{l}\text { Persentase } \\
(\%)\end{array}$ \\
\hline Lama & 37 & 54,4 \\
Tidak Lama & 31 & 45,6 \\
\hline Jumlah & 68 & 100,0 \\
\hline
\end{tabular}

Berdasarkan tabel 1 di atas, dapat diketahui bahwa dari 68 akseptor KB di Desa Jelantik, Kecamatan Jonggat, sebagian besar responden 
sudah lama menggunakan KB suntik, yaitu sejumlah $37(54,4 \%)$.

Tabel 2 Distribusi Frekuensi Berdasarkan Gangguan Menstruasi

pada Akseptor KB di di Desa Jelantik,

Kecamatan Jonggat

\begin{tabular}{lcc}
\hline $\begin{array}{l}\text { Gangguan } \\
\text { Menstruasi }\end{array}$ & Frekuensi & $\begin{array}{c}\text { Persentase } \\
(\%)\end{array}$ \\
\hline Ya & 50 & 73,5 \\
Tidak & 18 & 26,5 \\
\hline Jumlah & 68 & 100,0 \\
\hline
\end{tabular}

Berdasarkan tabel 5.2 di atas, dapat diketahui bahwa dari 68 akseptor KB di di Desa Jelantik, Kecamatan Jonggat, sebagian besar telah mengalami gangguan menstruasi, yaitu sejumlah 50 orang $(73,5 \%)$.

2. Analisis Bivariat

Tabel 3 Hubungan antara Hubungan Lama Pemakaian KB Suntik dengan Gangguan Menstruasi pada Akseptor KB di Desa Jelantik

\begin{tabular}{|c|c|c|c|c|c|c|c|}
\hline \multirow{3}{*}{$\begin{array}{l}\text { Lama } \\
\text { Pemakaian }\end{array}$} & \multicolumn{4}{|c|}{$\begin{array}{l}\text { Gangguan } \\
\text { Menstruasi }\end{array}$} & \multirow{2}{*}{\multicolumn{2}{|c|}{ Total }} & \multirow{3}{*}{$\begin{array}{c}\mathrm{P}- \\
\text { value }\end{array}$} \\
\hline & \multicolumn{2}{|c|}{$\mathrm{Ya}$} & \multicolumn{2}{|c|}{ Tidak } & & & \\
\hline & $\mathrm{F}$ & $\%$ & $f$ & $\%$ & $\mathrm{f}$ & $\%$ & \\
\hline Lama/ >2x & 33 & 89,2 & 4 & 10,8 & 37 & 100 & 0,003 \\
\hline Tidak Lama/ $2 \mathrm{x}$ & 17 & 54,8 & 14 & 45,2 & 31 & 100 & 0,042 \\
\hline Jumlah & 50 & 73,5 & 18 & 26,5 & 68 & 100 & \\
\hline
\end{tabular}

Berdasarkan tabel 5.7 di atas, dapat diketahui bahwa responden yang sudah lama menggunakan $\mathrm{KB}$ suntik yang mengalami gangguan menstruasi sejumlah 33 orang $(89,2 \%)$, sedangkan responden yang tidak lama menggunakan $\mathrm{KB}$ suntik yang mengalami gangguan menstruasi sejumlah 17 orang $(54,8 \%)$. Ini menunjukkan bahwa gangguan menstruasi lebih banyak terjadi pada responden yang sudah lama menggunakan KB suntik dibandingkan yang belum lama menggunakan.

Berdasarkan uji Chi Square didapat nilai Chi Square (Continuity Correction) sebesar 8,537 dengan p-value 0,003. Oleh karena pvalue $=0,003>\alpha(0,05)$, disimpulkan bahwa ada hubungan yang signifikan. Dari hasil juga diperoleh nilai Odds Ratio 6,794, ini artinya responden yang lama/ $>2 \mathrm{x}$ pemakaian, memakai KB suntik beresiko 6,794 kali lebih besar mengalami gangguan menstruasi dibandingkan responden yang belum lama menggunakan.

\section{Pembahasan}

Kontrasepsi suntik yang sering digunakan masyarakat yaitu suntik 3 bulan (DMPA) dengan daya kerja kontraseptif yang paling sering dipakai - $150 \mathrm{mg}$ setiap 3 bulan dan Cyclofem dalam kemasan 0,5 $\mathrm{ml}$ suspensi aqueus steril yang berisi $25 \mathrm{mg}$ Medroxyprogesterone asetat $+5 \mathrm{mg}$ Estradiol cypionate. Berdasarkan penelitian yang dilakukan di Desa Jelantik dari 68 responden $\mathrm{KB}$ suntik, yang menggunakan KB suntik 3 bulan (DMPA) sebanyak 49 responden $(72,1 \%)$ dan yang menggunakan KB suntik 1 bulan ( Cyclofem) sebanyak 19 responden (27,9\%). Hal ini menggambarkan bahwa pengguna KB suntik 3 bulan (DMPA) lebih banyak daripada pengguna KB suntik 1 bulan (Cyclofem). Akseptor lebih memilih kontrasepsi suntik DMPA karena kerugian yang ditimbulkan dari kontrasepsi suntik Cyclofem yaitu, penyuntikan yang lebih sering, biaya keseluruhan lebih tinggi dan ketergantungan klien terhadap pelayanan kesehatan, klien harus kembali setiap 30 hari untuk mendapatkan suntikan.

Berdasarkan hasil penelitian dari 49 akseptor KB suntik DMPA, sebagaian besar sudah lama menggunakan KB suntik yaitu sebanyak 27 akseptor, kemudian dari 19 akseptor KB suntik cyclofem sebagian besar juga sudah lama menggunakan KB suntik yaitu sebanyak 10 akseptor. Lama pemakaian kontrasepsi suntik adalah jangka waktu pemakaian kontrasepsi suntik yang digunakan pada wanita dari pasangan usia subur. Pada penelitian lain juga rata-rata akseptor $\mathrm{KB}$ suntik relatif sudah lama menggunakan dilihat dari hasil penelitian Selvia Wedhayanti Putri, Hubungan Antara Lama Pemakaian KB Suntik 
DMPA dengan Kejadian Amenorhea pada Akseptor KB Suntik DMPA Di RB Kusmahati Karanganyar. Dengan hasil penelitian jumlah responden yang lama menggunakan KB suntik DMPA yaitu sebanyak 25 responden (54,3\%).

Pemakaian kontrasepsi suntik sangat mudah karena kontrasepsi suntik dapat dipakai segera setelah melahirkan, cocok untuk mencegah kehamilan atau menjarangkan kehamilan dalam jangka panjang karena kesuburan akan cepat pulih kembali, suntik juga tidak mengganggu hubungan suami istri, lebih hemat biaya karena suntikan ulang 3 bulan sekali untuk pengguna DMPA dan 1 bulan sekali untuk Cyclofem, tidak seperti kontrasepsi pil yang harus diminum setiap hari, serta tidak mengganggu proses menyusui.

Gambaran gangguan menstruasi dari 68 responden akseptor KB suntik, 49 akseptor $\mathrm{KB}$ suntik DMPA sebagian besar mengalami gangguan menstruasi yaitu sebanyak 38 akseptor, sedangkan dari 19 akseptor KB suntik cyclofem sebagian besar juga mengalami gangguan menstruasi yaitu sebanyak 12 akseptor. Gangguan menstruasi yang dialami akseptor sesuai dengan teori yang di kemukakan Perdarahan banyak atau memanjang (lebih dari delapan hari atau dua kali lebih banyak dari perdarahan yang biasanya dialami pada siklus normal) merupakan perdarahan yang banyak atau memanjang tersebut biasanya ditemukan pada bulan awal setelah disuntik [3]. Pada penelitian lain yang dilaksanakan di Perumahan Petragriya Indah purwodadi pada tahun 2008 dendan judul Hubungan Lama Pemakaian Depo Medroxy Progesteron Asetat dengan Gangguan Menstruasi di Perumahan Petragriya Indah purwodadi dengan hasil dari 54 responden penelitian hampir sebagian besar mengalami perubahan pola haid. Perdarahan tersebut berupa perubahan siklus, lama dan kejadian spoting.

Efek samping utama gangguan menstruasi, hal lain yang dirasakan atau efek samping yang dialami akseptor KB suntik adalah nyeri kepala, pusing, nyeri payudara dan mual, hal ini sesuai dengan teori yang di kemukakan Glasier dan Gebbie yaitu semua metode progesteron dapat menyebabkan nyeri kepala, pusing, mual, perubahan suasana hati, gembung abdomen, nyeri payudara. Gejalagejala ini biasanya mereda dalam beberapa bulan pertama. Akan tetapi gejala tersebut belum jelas apakah benar-benar disebabkan oleh metode progesteron karena hampir semua gejala diatas sering terjadi dalam kehidupan sehari-hari.

Hubungan lama pemakaian kontrasepsi KB suntik DMPA dengan gangguan menstruasi digunakan uji Chi Square, berdasarkan hasil penelitian diketahui bahwa responden yang sudah lama menggunakan KB suntik DMPA yang mengalami gangguan menstruasi sebanyak 25 akseptor $(92,6 \%)$. Sedangkan responden yang tidak lama menggunakan KB suntik DMPA yang mengalami gangguan menstruasi sebanyak 13 orang $(59,1 \%)$, hal ini menunjukkkan bahwa gangguan menstruasi lebih banyak terjadi pada ibu yang sudah lama menggunakan KB suntik DMPA dibandingkan yang tidak lama menggunakan.

Berdasarkan hasil uji chi square didapat $\mathrm{p}$ value $=0,007$. Oleh karena $\mathrm{p}$-value $=0,007<\alpha$ $(0,05)$, disimpulkan bahwa ada hubungan yang signifikan antara lama pemakaian KB suntik DMPA dengan gangguan menstruasi pada akseptor KB baru di Desa Jelantik. Dari hasil juga diperoleh nilai Odds Ratio 8,654, ini artinya responden yang lama memakai KB suntik DMPA beresiko 8,654 kali lebih besar mengalami gangguan menstruasi dibandingkan responden yang tidak lama menggunakan. Glasier dan Gebbie, 2006 pada sebagian pemakai kontrasepsi suntik, terjadi peningkatan insidensi bercak darah yang tidak teratur dan sedikit atau perdarahan diluar siklus, oligomenoria, bercak darah atau perdarahan yang berkepanjangan atau sering atau bahkan amenoria, pola dapat berubah seiring dengan waktu atau lama penggunaan kontrasepsi.

Hasil penelitian lain juga menyatakan 
bahwa ada hubungan antara lama pemakaian kontrasepsi DMPA dengan gangguan menstruasi. Penelitian dilakukan oleh Amruni dengan judul Hubungan Lama Pemakaian DMPA Dengan Gangguan Menstruasi di BPS Ny. Sri Handayani Desa Dorolegi Kecamatan Godong Kabupaten Grobogan tahun 2009. Dengan hasil penelitian sebagian besar ibu atau responden yang lama menggunakan kontrasepsi DMPA mengalami gangguan menstruasi. Keluhan terbanyak para pemakai KB suntik adalah gangguan perdarahan, baik berupa amenorhea, perdarahan bercak, dan haid tidak teratur. Hampir $40 \%$ kasus mengeluh gangguan haid sampai akhir tahun pertama suntikan.

Eefek samping utama penggunaan KB suntik adalah gangguan pola haid seperti amenore, perdarahan bercak, perubahan dalam frekuensi, lama dan jumlah darah yang hilang. Efek pola haid tergantung pada lama pemakaian, perdarahan inter-menstrual dan perdarahan bercak berkurang dengan berjalannya waktu, sedangkan kejadian amenore bertambah besar. Kejadian amenore dengan gangguan menstruasi didukung juga dengan hasil penelitian yang dilakukan oleh Norma Fitriana, dengan judul Hubungan Penggunaan Kontrasepsi Suntik 3 Bulan dengan Kejadian Amenorhea di Bidan Praktek Swasta Nilawati Balikpapan. Dengan hasil dari 60 responden yang mengalami gangguan menstruasi berupa amenorhea sebanyak 36 responden (60\%). Amenore yang lama dan perdarahan yang lama sebab utama dari ketidak puasan akseptor. Ketidak puasan akseptor dengan kontrasepsi suntik berasal dari gangguan pola haid yang ditimbulkan. Perdarahan ireguler menyebabkan 20-25\% akseptor menghentikan suntikan. Akan tetapi kontinuitas dari kontrasepsi suntikan sangat bervariasi, $50-75 \%$ akseptor tetap menggunakannya setelah/sampai 1 tahun.

Meskipun hasil penelitian ini menunjukkan adanya hubungan lama pemakaian DMPA dengan gangguan menstruasi. Gangguan menstruasi juga bisa dipengaruhi beberapa faktor antara lain status gizi, penyakit, umur, psikologi, dan penggunaan obat-obat tetrentu.

Hubungan lama pemakaian kontrasepsi KB suntik cyclofem dengan gangguan menstruasi digunakan uji Chi Square, berdasarkan hasil penelitian diketahui bahwa responden yang sudah lama menggunakan KB suntik cyclofem yang mengalami gangguan menstruasi sebanyak 8 akseptor $(80,0 \%)$. Sedangkan responden yang tidak lama menggunakan KB suntik Cyclofem yang mengalami gangguan menstruasi sebanyak 4 orang $(44,4 \%)$, hal ini menunjukkkan bahwa gangguan menstruasi lebih banyak terjadi pada ibu yang sudah lama menggunakan KB suntik DMPA aibandingkan yang tidak lama menggunakan.

Berdasarkan hasil uji didapat $\mathrm{p}$-value $=$ 0,170 . Oleh karena $p$-value $=0,170>\alpha(0,05)$, disimpulkan bahwa tidak ada hubungan yang signifikan antara lama pemakaian KB suntik Cyclofem dengan gangguan menstruasi pada akseptor KB baru di Desa Jelantik. pada ibu akseptor KB suntik Cyclofem tidak hanya akan mengalami gangguan menstruasi akan tetapi ada efek samping lain yaitu seperti mual, sakit kepala, dan perubahan tekanan darah. Dari salah satu efek samping tersebut ada penelitian yang menyatakan bahwa adanya perbedaan tekanan darah yang dialami akseptor KB cyclofem dengan judul Perbedaan Tekanan Darah pada Akseptor KB Setelah Penggunaan KB Suntik Kombinasi Selama 4 Bulan . Kejadian perubahan tekanan darah meningkat sampai 2-3 kali lipat setelah 4 bulan penggunaan kontrasepsi kombinasi yang mengandung estroge. Keuntungan dari penggunaan kontrasepsi cyclofem adalah kurang menimbulkan perdarahan bercak atau perdarahan ireguler lainnya, kurang menimbulkan amenore, efek samping lebih cepat menghilang setelah suntikan dihentikan. Akan tetapi sekitar 8-26\% akseptor berhenti karena persoalan-persoalan perdarahan. 


\section{KESIMPULAN}

Hasil penelitian yang dilakukan dalam melihat hubungan lama pemakaian KB suntik dengan gangguan menstruasi adalah ada hubungan antara lama pemakian $\mathrm{KB}$ suntik DMPA dengan gangguan menstruasi. Sedangkan, tidak ada hubungan antara lama pemakaian KB suntik Cyclofem dengan gangguan menstruasi.

\section{DAFTAR PUSTAKA}

[1] Pusat Data dan Informasi. 2013. "Situasi dan Analisis Keluarga Berencana". Kementerian Kesehatan RI. Jakarta.

[2] Anggraini dan Martini, 2011. Pelayanan Keluarga Berencana. Yogyakarta : Rohima Press

[3] Sulistiawati, 2011. Pelayanan Keluarga Berencana. Jakarta : Selemba Medika 